See discussions, stats, and author profiles for this publication at: https://www.researchgate.net/publication/275344511

\title{
Effect of starch-based supplementation level combined with oil on intake, performance, and methane emissions of growing Nellore bulls on pasture
}

Article in Journal of Animal Science · February 2015

DOI: $10.2527 /$ jas $2014-8500$

CITATIONS

6 authors, including:

A. Jose Neto

São Paulo State University

31 PUBLICATIONS 33 CITATIONS

SEE PROFILE

19

Andressa Ferreira Ribeiro

São Paulo State University

16 PUBLICATIONS 89 CITATIONS

SEE PROFILE

Some of the authors of this publication are also working on these related projects:

Project GHG full account and mitigation strategies in Brachiaria pastures submitted to different management View project

Project Impact of metabolizable protein in the production of beef cattle and emission of greenhouse gases View project
READS

212

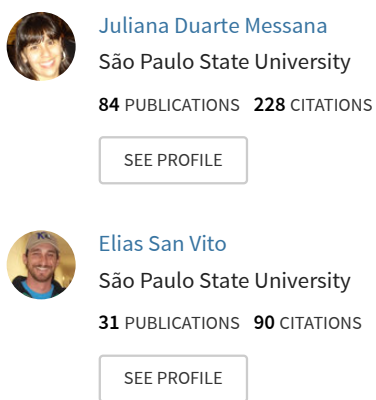




\title{
Effect of starch-based supplementation level combined with oil on intake, performance, and methane emissions of growing Nellore bulls on pasture ${ }^{1}$
}

\author{
A. Jose Neto, ${ }^{2}$ J. D. Messana, A. F. Ribeiro, E. S. Vito, L. G. Rossi, and T. T. Berchielli ${ }^{3}$ \\ Departamento de Zootecnia da Universidade Estadual Paulista (UNESP), \\ Faculdade de Ciências Agrárias e Veterinárias, Jaboticabal, São Paulo, Brazil
}

\begin{abstract}
Intake of tropical grass forages alone is generally insufficient to avoid nutrition imbalances and reduced animal performance; therefore, supplementation is often recommended. The hypothesis of the present study is that when combined with fat, soybean hulls $(\mathrm{SH})$ could replace corn as a source of energy, reducing methane production without affecting animal performance. This study evaluated the effects of starch-based supplementation level combined with oil on intake, digestibility, performance, and methane emissions of growing Nellore bulls ( $n=44$; initial $\mathrm{BW}=250.69 \pm 27 \mathrm{~kg}$ ) fed Brachiaria brizantha $\mathrm{cv}$. Xaraés during the rainy season. There were no interactions between starch level and oil supplementation with regard to intake of DM $(P=0.67)$, forage DM $(P=0.55)$, supplement DM $(P=0.14), \mathrm{OM}(P=0.66)$, $\mathrm{CP}(P=0.74)$, NDF $(P=0.50)$, ether extract $(\mathrm{EE}$; $P=0.47)$, and GE $(P=0.68)$. The intake of EE was greater for animals supplemented with oil than those fed supplements without oil $(P<0.01)$. There were no interactions between starch level and oil supplementation on digestibility of $\mathrm{DM}(P=0.18), \mathrm{OM}(P=0.11)$,
\end{abstract}

NDF $(P=0.42)$, and EE $(P=0.14)$. Moreover, there was interaction between starch and oil supplementation on GE $(P<0.01)$. Independent of starch level used, the addition of oil decreased the digestibility of $\mathrm{OM}$ $(P=0.04)$ and NDF $(P=0.03)$. There were no main effects of starch level, oil, or interaction between starch and oil for initial BW $(P=0.10)$, final BW $(P=0.94)$, ADG $(P=0.40)$, feed efficiency $(P=0.37)$, and carcass gain $(P=0.38)$. There was no interaction between starch-based supplementation level and oil on methane emissions when expressed in grams per day $(P=0.77)$, kilograms per year $(P=0.77)$, grams per kilogram DMI $(P=0.53)$, and grams per kilogram carcass gain $(P=0.31)$. There was, however, an interaction $(P=$ 0.04 ) between starch level and oil on methane emissions when corrected for NDF intake. Additionally, oil decreased enteric methane emission for intake of GE $(P=0.04)$ and $\mathrm{EE}(P<0.01)$ of animals fed with starch level. Soybean hulls have an estimated feeding value similar to that of corn. The use of oil supplementation may be effective to reduce enteric methane emission of Nellore bulls raised on pasture.

Key words: corn, greenhouse gases, ruminant, soybean hulls, tropical grass

(C) 2015 American Society of Animal Science. All rights reserved.

J. Anim. Sci. 2015.93 doi:10.2527/jas2014-8500

\section{INTRODUCTION}

Feeding systems based exclusively on tropical grass may compromise optimal cattle growth. Even

\footnotetext{
${ }^{1}$ We thank the São Paulo Research Foundation (FAPESP) grant \#2012/08284-5 for funding this research, and Cargill for providing feed supplies for experimental supplements.

${ }^{2}$ Corresponding author: antoniojoseneto@yahoo.com.br

${ }^{3}$ Membro INCT/CA - UFV - Departamento de Zootecnia, Viçosa, Minas Gerais, Brazil.

Received September 9, 2014.

Accepted February 22, 2015.
}

though the nutritive value of grasses is greater in the rainy season, as indicated by increased $\mathrm{CP}$ content, nutrient imbalances are still present (Detmann et al., 2008). Indeed, $N$ utilization in grazing beef cattle is often low due to high concentrations of rapidly soluble and degradable protein in pasture-based diets if energy is not simultaneously available. Under these circumstances, supplementation with energy is often recommended (Higgs et al., 2013).

Supplements may affect ruminal fermentation in different ways, depending on the chemical forms of carbohydrates in their composition (Costa et al., 2009). When starch-based supplements are provided 
in conjunction with forage-based diets, DMI and fiber digestion are often reduced and so are methane emissions (Moss et al., 2000). Soybean hulls (SH), in turn, have been shown to be an energy source comparable to corn (Santana et al., 2013), but their effect on fiber digestion is not as intensive (Ludden et al., 1995).

The addition of fats to ruminant diets has also been recommended, as it similarly increases energy efficiency and hence reduces methanogenesis. Although greater concentrations of fats substantially decrease methane production, they often exert detrimental effects on fiber digestion and, consequently, animal performance (Patra, 2013).

There have been few studies to date that investigated the combined effect of different carbohydrate forms and oil sources on animal performance and methane emission. The hypothesis of the present study is that when combined with fat, $\mathrm{SH}$ could replace corn as a source of energy and reduce methane production without affecting performance. This study evaluated the combined effects of high- or low-starch supplements and oil on intake, digestibility, performance, and methane emissions of young Nellore bulls fed Brachiaria brizantha $\mathrm{cv}$. Xaraés during the rainy season.

\section{MATERIALS AND METHODS}

The protocol used in this experiment was in accordance with the Brazilian College of Animal Experimentation (Colégio Brasileiro de Experimentação Animal) guidelines and was approved by the Ethics, Bioethics, and Animal Welfare Committee (Comissão de Ética e Bem Estar Animal) of the Faculty of Agriculture and Veterinary Sciences - São Paulo State University (UNESP) Jaboticabal campus (protocol number 021119/11).

\section{Animals and Management}

The experiment was conducted at the UNESP (Jaboticabal, SP, Brazil) from December 2012 to May 2013, in the rainy season. Under the international Köppen classification, this climate is characterized as tropical type AWA with summer rains and relatively dry winter; the local altitude is $595 \mathrm{~m}$ and it is located at $21^{\circ} 15^{\prime} 22^{\prime \prime} \mathrm{S}, 48^{\circ} 18^{\prime} 58^{\prime \prime} \mathrm{W}$.

Forty-four Nellore bulls were used in the experiment, with an average age of $15 \mathrm{mo}$ and initial $\mathrm{BW}=$ $250.69 \pm 27 \mathrm{~kg}$. Carcass gain $(\mathbf{C r G})$ was determined via the comparative slaughter technique. Eight animals $(275.16 \pm 35 \mathrm{~kg})$ were slaughtered at a commercial beef plant and served as the reference group at the beginning of the experiment as the initial dressing percentage (DP; 50.93\%), which estimated the initial carcass weight to obtain the $\mathrm{CrG}$ at the end of experiment. The 8 animals slaughtered were taken from a random sample.

After $133 \mathrm{~d}$ of feeding, another 8 animals were slaughtered at the commercial beef plant and served as the reference group at the end of the experiment, with DP of $52.02 \%$. The 8 animals slaughtered were taken from a random sample, with 2 animals per treatment. Carcass gain was obtained using the final estimated carcass weight (final BW $\times$ DP of final reference group) minus initial estimated carcass weight (initial BW $\times$ DP of initial reference group) per number of days feeding. Preharvest handling was in accordance with good animal welfare practices, and slaughtering procedures followed the Sanitary and Industrial Inspection Regulation for Animal Origin Products (Brasil, 1997). After the slaughter, all the carcasses were weighed and refrigerated at $4^{\circ} \mathrm{C}$ for approximately $24 \mathrm{~h}$.

The experimental period lasted $133 \mathrm{~d}$, divided into an adaptation period of $21 \mathrm{~d}$ and 4 periods of $28 \mathrm{~d}$ each. Initially, the animals were weighed, identified, treated against ecto- and endoparasites by administration of ivermectin (Ivomec; Merial, Paulínea, Brazil), and allocated into 12 paddocks of 1.8 ha, consisting of Brachiaria brizantha cv. Xaraés. The animals were distributed in a completely randomized design (3 animals per paddock and 3 paddocks per treatment).

Grazing method used was continuous stocking with variable stocking rate ("put and take" stocking), with the use of regulator animals, with the objective of maintaining the sward height of $35 \mathrm{~cm}$. Control of the stocking rate was done weekly as a function of the predetermined forage heights; that is, when the height was greater than expected for that treatment, animals were added, and in the inverse situation, animals were removed.

Forage height was randomly measured weekly by 80 points using a graduated stick in each paddock (Barthram, 1985). Samples to address herbage chemical composition were obtained by hand plucking (Johnson, 1978). Hand plucking was performed on the same days as the estimation of DMI, described later. The simulation of grazing per paddock was performed every $28 \mathrm{~d}$.

The diets used consisted of starch level with or without a source of oil. The supplements were corn associated or not with soybean grain and $\mathrm{SH}$ associated or not with soybean grain. Crude glycerin is a byproduct from the biodiesel agroindustry and can be used in ruminant diets without compromising intake and performance (Drouillard, 2012; Parsons et al., 2009). This byproduct was used in all supplements to replace ( $28 \%$ of DM) corn or SH. Crude glycerin $(83.90 \%$ glycerol, $1.75 \%$ ether extract [EE], $4.30 \%$ ash, and $12.01 \%$ water) was acquired from a soybean-oil-based biodiesel production company (Cargill, Três Lagoas, Mato Grosso do 
Sul, Brazil). The proportion of ingredients and chemical composition of supplements are presented in Table 1.

Animals were supplemented at the rate of $500 \mathrm{~g} / 100 \mathrm{~kg}$ of BW, daily, at $1000 \mathrm{~h}$ and had ad libitum access to water and shade. Every $28 \mathrm{~d}$, the animals were weighed after a 16-h period of withdrawal from feed and water, and this BW was used to adjust the amount of supplement. Average daily gain was obtained by weighing the animal at the beginning and the end of the experiment, always after a $16-\mathrm{h}$ period of withdrawal from feed and water.

\section{Proximate Analysis}

For proximate analysis, the sample of ingredients of supplements, forage, and feces were dried at $55^{\circ} \mathrm{C}$ for 72 $\mathrm{h}$. Samples were then ground in a Wiley mill (Thomas Scientific, Swedesboro, NJ) to pass through a 1-mm screen and analyzed for DM (method 934.01), OM (method 942.05), and and EE (method 920.85) according to the Association of Official Analytical Chemists (AOAC, 1995). Concentrations of $\mathrm{N}$ in each sample were determined by rapid combustion $\left(850^{\circ} \mathrm{C}\right)$, conversion of all $\mathrm{N}$-combustion products to $\mathrm{N}_{2}$, and subsequent measurement by thermoconductivity cell (Leco model FP528; LECO Corporation, St. Joseph, MI). Crude protein was calculated as the percentage of $\mathrm{N}$ in the sample multiplied by 6.25 . The GE content of supplements, forage, and feces was determined using an adiabatic bomb calorimeter (model 6300; Parr Instrument Company, Moline, IL). Analyses for NDF were conducted following Van Soest et al. (1991) and adapted for the Ankom200 Fiber Analyzer (Ankom Technology, Fairport, NY).

\section{Intake Estimation}

Thirty-six animals were used to estimate intake and nutrient digestibility. Lignin isolated, purified, and enriched from Eucalyptus grandis (LIPE) and indigestible NDF (iNDF) were used to estimate the excretion of fecal matter (as dry weight) and forage intake, respectively.

Lignin isolated, purified, and enriched from Eucalyptus grandis was provided for $7 \mathrm{~d}$ by oral administration of a 500-mg bolus, with $4 \mathrm{~d}$ to stabilize fecal excretion of the marker, and in the last $3 \mathrm{~d}$ for sample collection (Saliba, 2005). Fecal samples were collected during $3 \mathrm{~d}$, directly from the rectum, at 1600 , 1100 , and $0700 \mathrm{~h}$ on the first, second, and third day of collection, respectively. The fecal samples were dried at $55^{\circ} \mathrm{C}$ for $72 \mathrm{~h}$ and ground in a Wiley mill (Thomas Scientific) to pass through a $1-\mathrm{mm}$ screen and composited proportionately on each of $3 \mathrm{~d}$ of sampling, within each animal, based on fecal dry weights. Approximately $10 \mathrm{~g}$ of each composited sample of fe-
Table 1. Experimental supplement and chemical composition of supplements and pasture (\% DM basis)

\begin{tabular}{|c|c|c|c|c|c|}
\hline \multirow[b]{2}{*}{ Item } & \multicolumn{2}{|c|}{ High starch } & \multicolumn{2}{|c|}{ Low starch } & \multirow[b]{2}{*}{ Pasture $^{1}$} \\
\hline & Oil & No oil & Oil & No oil & \\
\hline \multicolumn{6}{|l|}{ Ingredient proportions } \\
\hline Corn & 8.90 & 18.5 & 0.00 & 0.00 & - \\
\hline Soybean meal & 0.00 & 49.0 & 0.00 & 49.0 & - \\
\hline Soybean hulls & 0.00 & 0.00 & 8.50 & 18.5 & - \\
\hline Grain soybean & 58.6 & 0.00 & 59.0 & 0.00 & - \\
\hline Crude glycerin & 28.0 & 28.0 & 28.0 & 28.0 & - \\
\hline Commercial premix ${ }^{2}$ & 4.50 & 4.50 & 4.50 & 4.50 & - \\
\hline \multicolumn{6}{|l|}{ Chemical composition } \\
\hline $\mathrm{DM}$ & 90.9 & 88.1 & 90.2 & 88.2 & 90.5 \\
\hline $\mathrm{CP}$ & 27.6 & 26.5 & 26.2 & 26.0 & 12.8 \\
\hline $\mathrm{NDF}$ & 13.2 & 11.0 & 17.5 & 20.2 & 59.0 \\
\hline $\operatorname{Starch}^{3}$ & 11.0 & 16.3 & 4.79 & 3.52 & - \\
\hline Ether extract & 13.8 & 3.18 & 13.4 & 2.57 & 1.32 \\
\hline GE, Mcal/kg DM & 5.16 & 4.51 & 5.07 & 4.41 & 4.45 \\
\hline
\end{tabular}

${ }^{1}$ Average and SD of the mean of samples obtained by technique of simulated grazing in 5 periods.

${ }^{2} 120 \mathrm{~g}$ calcium, $30 \mathrm{~g}$ phosphorus, $25 \mathrm{~g}$ sulfur, $80 \mathrm{~g}$ sodium, $330 \mathrm{mg}$ copper, $950 \mathrm{mg}$ manganese, 1,220 mg zinc, $24 \mathrm{mg}$ iodine, $20 \mathrm{mg}$ cobalt, $6 \mathrm{mg}$ selenium, and $300 \mathrm{mg}$ fluorine.

${ }^{3}$ Calculated based on ingredient values from Valadares Filho et al., 2010.

ces was sent to the Federal University of Minas Gerais (Belo Horizonte, MG, Brazil) to estimate the total daily fecal output by 2 methods of LIPE measurement as described by Saliba (2005). Individual concentrate intake was estimated by dividing the total concentrate provided by the number of animals in each paddock.

The individual intakes of forage were estimated using the internal marker iNDF. The samples of feces, forage, and concentrate were placed in ANKOM bags (filter bag F57; ANKOM Technology Corporation) and incubated in the rumen of a fistulated Nellore animal for a period of $288 \mathrm{~h}$ (Valente et al., 2011). When the bags were withdrawn from the rumen, they were soaked in water for $30 \mathrm{~min}$ and gently washed by hand under running water until the wash water ran clear. The bags were then placed in an ANKOM 200 fiber analyzer (ANKOM Technology Corporation), as described by Mertens (2002), and the iNDF was determined by weighing the bags with a digital scale after drying them in an oven, first at $55^{\circ} \mathrm{C}$ for $72 \mathrm{~h}$ and then at $105^{\circ} \mathrm{C}$ for $12 \mathrm{~h}$. The residue was considered the iNDF. Individual forage intakes were estimated by subtracting marker excretion from the concentrate from the total iNDF excretion and dividing that difference by the concentration of the marker in the forage.

\section{Methane Measurements}

The methane emissions were assessed using the sulfur hexafluoride $\left(\mathrm{SF}_{6}\right)$ tracer technique (Johnson et 
al., 1994), in which each animal was sampled daily for 6 consecutive 24-h days, beginning on d 65 of feeding. Thirty-six animals were fitted with gas collection halters at $14 \mathrm{~d}$ before methane sampling to allow animals to adapt and facilitate sampling.

The release rate (RR) of the gas from a permeation tube is known before its insertion into the rumen. The permeation tubes were maintained in a water bath at $39^{\circ} \mathrm{C}$ and weighed in the laboratory for $7 \mathrm{wk}$. The average $\mathrm{RR}$ was similar among the treatments $(\mathrm{RR}=$ $1.90 \pm 0.2 \mathrm{mg} \mathrm{SF}_{6} / \mathrm{d}$, mean $\pm \mathrm{SD}$ ). Brass permeation tubes filled with $\mathrm{SF}_{6}$ and known $\mathrm{RR}$ were administered orally to each of the 36 animals $72 \mathrm{~h}$ before methane sampling to allow the tracer gas to equilibrate in the rumen. The animals were fitted with gas collection halters connected to pre-evacuated polyvinyl chloride (PVC) canisters designed to fill halfway over $24 \mathrm{~h}$. Eructated gas sampling started at $0700 \mathrm{~h}$ daily, when the animals were removed from the paddocks, and was conducted at the management center (stockyard) to facilitate sampling.

The collection canisters were located above each animal to reduce the risk of equipment damage and were connected to the halter by tubing inside airline flexible-coil tubing. Collection canisters, constructed of PVC pipe, were attached to a vacuum pump in the laboratory to create a negative pressure. As the vacuum in the sampling canister was slowly dissipated, the negative pressure steadily drew the sample of air from around the mouth and nose of the animal. The pressure of the canister, removed from the animal, was measured after $24 \mathrm{~h}$ of collection and if the final pressure was out of the expected range, the halter was preventively replaced. If the final pressure was above the expected range, the halter was probably blocked or disconnected; if the final pressure was below the expected range, possibly there was a leak in the system. In both situations, a new halter was placed on the animal with an average absorption rate within the stipulated range (fill halfway over $24 \mathrm{~h}$ ).

After sampling (approximately $30 \mathrm{~min}$ ), each animal was brought to the original paddock for feeding. The pressure readings were recorded, and the canisters were pressurized using pure N2. Additional canisters were placed near the experimental pasture to monitor background levels of methane and $\mathrm{SF}_{6}$ daily during each sampling period. These values were subtracted from the animals' values to calculate the net output in the expired breath. The concentrations of $\mathrm{CH}_{4}$ and $\mathrm{SF}_{6}$ in the collection tubes were measured at the Laboratory of Animal Nutrition - UNESP (Jaboticabal, SP, Brazil) using an gas chromatography (GC-2014, Shimadzu, Kyoto, Japan) equipped with column Porapak Q ( $2 \mathrm{~m}$ x $3 \mathrm{~mm}$ i.d., 80 to 100 mesh, Shimadzu, Kyoto, Japan), flame ionization detector for methane, and electron capture detector for hexafluoride, as described by Johnson et al. (1994).

Methane flux produced by animals was calculated in relation to the $\mathrm{SF}_{6}$ tracer gas flux from a permeation capsule lodged in the rumen minus the basal $\mathrm{CH}_{4}$ concentration in the air (Westberg et al., 1998).

The following equation was used:

$$
\mathrm{Q}_{\mathrm{CH} 4}=\mathrm{Q}_{\mathrm{SF} 6} \times\left(\left[\mathrm{CH}_{4}\right]_{y}-\left[\mathrm{CH}_{4}\right]_{b}\right) /\left[\mathrm{SF}_{6}\right],
$$

in which $\mathrm{Q}_{\mathrm{CH} 4}=\mathrm{CH}_{4}$ emission tax by animal, $\mathrm{Q}_{\mathrm{SF} 6}=$ know $\mathrm{SF}_{6}$ emission tax from capsule in rumen, $\left[\mathrm{CH}_{4}\right]_{y}=\mathrm{CH}_{4}$ concentrations in collection apparatus, $\left[\mathrm{CH}_{4}\right]_{b}=$ basal $\mathrm{CH}_{4}$ concentration, and $\left[\mathrm{SF}_{6}\right]=\mathrm{SF}_{6}$ concentration in collection apparatus.

\section{Statistical Analysis}

The experimental design was completely randomized in a $2 \times 2$ factorial arrangement (high or low starch, with or without a source of oil). Each paddock was considered the individual experimental unit (3 animals per paddock and 3 paddocks per treatment).

The mathematical model was represented by

$$
Y_{i j k}=\mu+\mathrm{S}_{i}+\mathrm{O}_{k}+\left(\mathrm{S}_{i} \times \mathrm{O}_{k}\right)+e_{i j k},
$$

in which $Y_{i j k}=$ observation of paddock $j$ subject to starch $i$ at oil inclusion $k, \mu=$ the overall mean, $\mathrm{S}_{i}=$ effect of starch $i=1$ and $2, \mathrm{O}_{k}=$ effect of oil inclusion $k=$ 1 and $2, \mathrm{~S}_{i} \times \mathrm{O}_{k}=$ interaction between starch $i$ and oil inclusion $k$, and $e_{i j k}=$ the residual experimental error.

The initial BW was used as a covariate for the statistical analysis of ADG.

The DM and nutrient intake, digestibility, feed efficiency (FE), CrG, and methane emission data were analyzed with starch level and oil inclusion as fixed effects and the residual error as a random effect using PROC MIXED of the SAS statistical software (SAS Inst. Inc., Cary, NC). Homogeneity of the data was verified using the UNIVARIATE procedure of SAS. Studentized residuals were plotted against the predicted values using the plot procedure to analyze data for outliers. The LSMEANS statement of the mixed procedure of SAS was used to calculate mean values. When the treatments were significant, the means were compared with Fisher's tests using the PDIFF option in LSMEANS command. The level of significance used to assess differences among means was $\alpha=0.05$.

\section{RESULTS}

There were no interactions between starch level and oil supplementation with regard to intake of DM 
Table 2. Effect of supplements containing high or low starch with or without oil (Oil or No Oil) on intake and digestibility of Nellore bull age (15 mo) in pasture

\begin{tabular}{|c|c|c|c|c|c|c|c|c|}
\hline \multirow[b]{2}{*}{ Item } & \multicolumn{2}{|c|}{ High starch $^{1}$} & \multicolumn{2}{|c|}{ Low starch ${ }^{2}$} & \multirow[b]{2}{*}{ SEM } & \multicolumn{3}{|c|}{$P$-value } \\
\hline & Oil & No Oil & Oil & No Oil & & Starch & Oil & Starch $\times$ oil \\
\hline \multicolumn{9}{|l|}{ Intake, $\mathrm{g} / \mathrm{kg}$ of BW } \\
\hline DM & 27.50 & 24.90 & 24.80 & 27.20 & 0.19 & 0.93 & 0.94 & 0.24 \\
\hline \multicolumn{9}{|l|}{ Intake, $\mathrm{kg} / \mathrm{d}$} \\
\hline $\mathrm{DM}$ & 7.70 & 7.69 & 7.45 & 7.85 & 0.47 & 0.92 & 0.69 & 0.67 \\
\hline Forage DM & 6.28 & 6.14 & 5.94 & 6.39 & 0.48 & 0.93 & 0.76 & 0.55 \\
\hline Supplement DM & 1.41 & 1.54 & 1.51 & 1.45 & 0.05 & 0.95 & 0.54 & 0.14 \\
\hline $\mathrm{OM}$ & 7.12 & 7.06 & 6.87 & 7.21 & 0.43 & 0.90 & 0.74 & 0.66 \\
\hline $\mathrm{CP}$ & 1.04 & 1.07 & 1.03 & 1.09 & 0.05 & 0.89 & 0.44 & 0.74 \\
\hline $\mathrm{NDF}$ & 3.96 & 3.86 & 3.83 & 4.13 & 0.28 & 0.80 & 0.74 & 0.50 \\
\hline Ether extract & 0.28 & 0.13 & 0.28 & 0.12 & 0.01 & 0.71 & $<0.01$ & 0.47 \\
\hline GE, Mcal/d & 35.11 & 34.13 & 33.93 & 34.70 & 2.08 & 0.88 & 0.96 & 0.68 \\
\hline \multicolumn{9}{|c|}{ Digestibility, g/kg DM } \\
\hline $\mathrm{DM}$ & 630.80 & 640.40 & 594.60 & 654.80 & 1.74 & 0.55 & 0.08 & 0.18 \\
\hline $\mathrm{OM}$ & 668.20 & 676.60 & 627.40 & 691.20 & 1.54 & 0.42 & 0.04 & 0.11 \\
\hline $\mathrm{NDF}$ & 601.70 & 643.10 & 594.20 & 678.10 & 2.50 & 0.59 & 0.03 & 0.42 \\
\hline Ether extract & 760.10 & 575.90 & 574.40 & 642.20 & 7.89 & 0.47 & 0.48 & 0.14 \\
\hline GE & $649.00^{\mathrm{ab}}$ & $628.20^{\mathrm{bc}}$ & $608.00^{c}$ & $664.50^{\mathrm{a}}$ & 1.02 & 0.82 & 0.11 & $<0.01$ \\
\hline
\end{tabular}

${ }^{\mathrm{a}-\mathrm{c}}$ Means within a row with different superscripts differ $(P<0.05)$.

${ }^{1}$ High starch: $136 \mathrm{~g} / \mathrm{kg}$ of starch in DM supplement.

${ }^{2}$ Low starch: $41.5 \mathrm{~g} / \mathrm{kg}$ of starch in DM supplement.

$(P=0.67)$, forage DM $(P=0.55)$, supplement DM $(P=0.14), \mathrm{OM}(P=0.66), \mathrm{CP}(P=0.74), \mathrm{NDF}(P=$ $0.50)$, EE $(P=0.47)$, and GE $(P=0.68)$. There was no effect of starch or oil on intake of DM, forage DM, supplement DM, OM, CP, NDF, and GE $(P>0.05)$. However, the addition of oil increased the intake of EE $(P<0.01)$ independent of starch level used (Table 2).

There were no interactions between starch level and oil supplementation on digestibility of $\mathrm{DM}(P=0.18)$, $\mathrm{OM}(P=0.11)$, NDF $(P=0.42)$, and EE $(P=0.14)$. There was an interaction between starch and oil supplementation on GE digestibility $(P<0.01)$. Therefore, animals supplemented with high starch and oil showed greater digestibility of GE than those supplemented with less starch and oil. Independent of starch level used, the addition of oil decreased the digestibility of $\mathrm{OM}(P=0.04)$ and NDF $(P=0.03$; Table 2$)$.

In relation to animal performance, there were no main effects of starch level, oil, or interaction between starch $\times$ oil for initial BW $(P=0.10)$, final BW $(P=0.94)$, ADG $(P=0.40)$, FE $(P=0.37)$, and $\mathrm{CrG}(P=0.38$; Table 3$)$.

Enteric methane emissions, expressed in grams per day $(P=0.77)$, kilograms per year $(P=0.77)$, grams per kilogram DMI $(P=0.53)$, and grams per kilogram CrG $(P=0.31)$, were not affected by the addition of oil or by the starch level supplemented to the animals. However, there was an interaction between starch level and oil on methane emissions when enteric methane emission was corrected for NDF intake $(P=0.04)$. Additionally, oil decreased enteric methane emissions relative to $\mathrm{GE}(P=0.04)$ and $\mathrm{EE}$ intake $(P<0.01)$ for animals fed high- or low-starch supplement (Table 4$)$.

\section{DISCUSSION}

This study evaluated the effects of starch-based supplementation level combined with oil on intake, digestibility, performance, and methane emissions of Nellore bulls fed Brachiaria brizantha cv. Xaraés. The addition of oil to the diet, independent of starch level used, was associated with reduced methane emissions but only when enteric methane was corrected for GE and $\mathrm{EE}$ intake. Animal performance, in turn, was compromised by the addition of oil independent of starch level used.

Fats can exert adverse effects on intake, digestibility, rumen fermentation, methane emissions, and performance of animals depending on the concentrations and type of fats in diets (Coppock and Wilks, 1991; Machmüller, 2006). In the current study, the effects of supplemental fat on intake of DM, forage DM, supplement DM, OM, CP, $\mathrm{NDF}$, and GE were not significant. This is consistent with previous observations of no reduction in DM intake when supplementing corn oil (2.36\%; Duckett et al., 2002), yellow grease (2 to 6\%; Zinn et al., 2000), or high-oil corn (Eibs et al., 2000; Duckett et al., 2002) for steer diets. The amount of fat to include in the diet should be determined based on the desirable energy concentration, in association with the other ingredients in the diet (e.g., high- vs. low-quality forage, saturation level of the fat, and fiber level in the diet; Hall and Eastridge, 2014). 
Table 3. Effect of supplements containing high- or low-starch sources with or without oil (Oil or No Oil) on initial and final BW, ADG, feed efficiency (FE), and carcass gain $(\mathrm{CrG})$ of Nellore bull age (15 mo) in pasture

\begin{tabular}{|c|c|c|c|c|c|c|c|c|}
\hline \multirow[b]{2}{*}{ Item } & \multicolumn{2}{|c|}{ High starch ${ }^{1}$} & \multicolumn{2}{|c|}{ Low starch ${ }^{2}$} & \multirow[b]{2}{*}{ SEM } & \multicolumn{3}{|c|}{$P$-value } \\
\hline & Oil & No Oil & Oil & No Oil & & Starch & Oil & Starch $\times$ oil \\
\hline Initial BW, kg & 239.45 & 259.11 & 257.55 & 246.66 & 8.49 & 0.74 & 0.61 & 0.10 \\
\hline Final BW, $\mathrm{kg}$ & 352.47 & 359.39 & 350.01 & 357.68 & 4.65 & 0.65 & 0.14 & 0.94 \\
\hline $\mathrm{ADG}, \mathrm{kg} / \mathrm{d}$ & 0.89 & 1.03 & 0.92 & 0.97 & 0.04 & 0.77 & 0.11 & 0.40 \\
\hline $\mathrm{FE}, \mathrm{kg} \mathrm{ADG} / \mathrm{kg}$ DM intake & 0.116 & 0.134 & 0.124 & 0.124 & 0.01 & 0.90 & 0.35 & 0.37 \\
\hline $\mathrm{CrG}, \mathrm{g} / \mathrm{d}$ & 0.46 & 0.52 & 0.47 & 0.49 & 0.02 & 0.83 & 0.11 & 0.38 \\
\hline
\end{tabular}

${ }^{1}$ High starch: $136 \mathrm{~g} / \mathrm{kg}$ of starch in DM supplement.

${ }^{2}$ Low starch: $41.5 \mathrm{~g} / \mathrm{kg}$ of starch in DM supplement.

Animals supplemented with oil in this study showed greater EE intake than those supplemented without oil: 37 and $16 \mathrm{~g} / \mathrm{kg}$ DM, respectively. Diets containing $70 \mathrm{~g}$ of EE/kg DM or more can cause feed degradation, be toxic to ruminal microorganisms, adhere to food particles, and create a physical barrier that prevents the action of microorganisms and microbial enzymes especially if there are great proportions of unsaturated fatty acids contained within the EE (Palmquist and Jenkins, 1980; Sullivan et al., 2004). Therefore, it can be concluded that there was no difference in intake due to the amount of oil consumed by animals.

In relation to the digestibility of the $\mathrm{DM}$ and nutrients, there was no difference between $\mathrm{SH}$ and corn. On the other hand, supplementation with oil decreased the digestibility of OM (5.3\%) and NDF (9.5\%) components for the animals fed both the low- and the highstarch supplement. This is likely due to a decrease in the number of rumen protozoa, various bacteria including fibrolytic bacterial populations, and decreased activity of fiber-degrading enzymes (Hristov et al., 2009; Huws et al., 2010; Patra and Yu, 2013; Yang et al., 2009). Fibrolytic bacteria are among the most sensitive to inhibition by dietary fats (Nagaraja et al., 1997).

Different forms of fat supplementation can affect NDF digestibility to a different extent. Oil seeds have less of a negative effect on fiber digestibility than oil supplementation. Oils may be readily adsorbed by fiber components of feeds in greater amounts than fats released from digestion of oil seeds, resulting in greater inhibitory effect on fiber digestion (Patra, 2013). In this study, the form of fat used was milled grain soybeans. This form of fat substantially decreased the digestibility of OM and NDF but did not exert detrimental effects on intake of animals.

In this study, there were no differences due to the main effect of starch source or an interaction between starch source and the presence of oil on final BW, $\mathrm{ADG}, \mathrm{FE}$, and $\mathrm{CrG}$. This is in line with the notion that in high-forage beef cattle diets, the nutritive value of $\mathrm{SH}$ is similar to that of corn (Anderson et al., 1988) and that possible changes in ruminal fermentation as- sociated with the different carbohydrate sources did not affect efficiency of feed use for growth.

Effects of SH on animal performance may be related to inclusion rate. At low inclusion rates, $\mathrm{SH}$ do not compromise performance because $\mathrm{SH}$ are fairly digestible compared with corn. Therefore, when included at low percentages of diet DM in concentrate diets, SH may reduce metabolic upsets, thereby increasing energy availability from other dietary components. In the case of forage-based diets, SH probably do not decrease fiber digestion as do starch-containing feedstuffs, such as corn. Consequently, energy intake may be enhanced by feeding SH compared with cereal concentrates (Ludden et al., 1995).

In relation to the performance characteristics, supplementation with addition of oil was compromised independent of starch level used. There was a numerical decrease of 9.5 (ADG) and $8.0 \%(\mathrm{CrG})$ for animals fed with oil compared to without oil. The inclusion of oil in the diet (40-50 g EE/kg DM) for cattle has the capacity to reduce digestibility and, therefore, may affect animal production performances (Chuntrakort et al., 2014). In this study, the supplementation with oil decreased the digestibility of OM (5.3\%) and NDF $(9.5 \%)$, indicating that feeds containing oil could contribute to the negative effect on digestibility those components. Our data agree with previous findings (Grainger et al., 2010; Lovett et al., 2003; McGinn et al., 2004) in that the addition of oil reduces digestibility.

The medium- and long-chain fatty acids can be inhibitory for gram-positive rumen bacteria, including ruminococcus cellulolytic bacteria, which could explain the low digestibility of the high roughage diet in the oil supplements (Dohme et al., 2000; Martin et al., 2008). The mechanism of reduced fiber digestibility caused by oil supplementation may also be related to the hydrogenation process of unsaturated fatty acids in the rumen. If the ability of the microorganisms to saturate the fatty acids was exceeded, then the unsaturated fatty acids would accumulate and interfere with microbial digestion (NRC, 2000). Therefore, diets containing oil ingredients should be used after con- 
Table 4. Effect of supplements containing high or low starch with or without oil (Oil or No Oil) on enteric methane emission of Nellore bull age $(15 \mathrm{mo})$ in pasture

\begin{tabular}{|c|c|c|c|c|c|c|c|c|}
\hline \multirow{2}{*}{$\begin{array}{l}\mathrm{CH}_{4} \\
\text { outputs }^{3}\end{array}$} & \multicolumn{2}{|c|}{ High starch $^{1}$} & \multicolumn{2}{|c|}{ Low starch ${ }^{2}$} & \multirow[b]{2}{*}{ SEM } & \multicolumn{3}{|c|}{$P$-value } \\
\hline & Oil & No Oil & Oil & No Oil & & Starch & Oil & Starch $\times$ oil \\
\hline $\mathrm{g} / \mathrm{d}$ & 117.74 & 127.63 & 114.61 & 120.48 & 6.95 & 0.48 & 0.28 & 0.77 \\
\hline $\mathrm{kg} / \mathrm{yr}$ & 42.97 & 46.58 & 41.83 & 43.97 & 2.53 & 0.48 & 0.28 & 0.77 \\
\hline $\mathrm{g} / \mathrm{kg}$ DMI & 15.36 & 17.14 & 15.45 & 15.44 & 1.37 & 0.57 & 0.54 & 0.53 \\
\hline $\mathrm{g} / \mathrm{kg}$ NDFI & $29.95^{b}$ & $39.18^{\mathrm{a}}$ & $30.11^{\mathrm{b}}$ & $29.42^{b}$ & 2.14 & 0.05 & 0.07 & 0.04 \\
\hline$\%$ of GEI & 3.37 & 4.38 & 3.39 & 3.49 & 0.23 & 0.10 & 0.04 & 0.08 \\
\hline g/g EEI & 0.42 & 1.10 & 0.40 & 0.99 & 0.03 & 0.16 & $<0.01$ & 0.24 \\
\hline $\mathrm{g} / \mathrm{kg} \mathrm{CrG}$ & 257.75 & 246.33 & 228.51 & 257.80 & 18.93 & 0.65 & 0.64 & 0.31 \\
\hline
\end{tabular}

sidering the effects of the optimum level of oil seed supplementation on animal performance.

Enteric methane emission expressed in grams per day, kilograms peryear, grams perkilogram of DMI, and grams per kilogram of $\mathrm{CrG}$ was not affected by supplementation with oil or by starch level. However, there was an interaction between starch level and oil on methane emissions when enteric methane emission was corrected for NDF intake. Supplement with high starch and without oil increased methane production by $23.9 \%$ compared to other supplements. The results demonstrated that the methanesuppressing effects of fats might be more marked with high concentrations of starch in diets. This probably occurs because fats may readily be adsorbed on to the fiber particles, which may lower the effective inhibitory concentrations in the rumen fluid or adsorption onto bacteria including methanogens (Patra, 2013). Consequently, this probably decreases the inhibitory effect of fats on methanogens in low-starch supplements. The in vivo study by Machmüller et al. (2003) revealed that the extent of inhibition of methanogenesis by fat might be lowered with high content of fibrous carbohydrate in diets.

On the other hand, regardless of starch level, the results this study demonstrated that the inclusion of oil in supplements of cattle on pasture mitigates when methane emission was corrected for EE intake $\left(\mathrm{g} \mathrm{CH}_{4} / \mathrm{g}\right.$ of EE intake). The oil supplementation significantly decreased enteric methane emission compared with supplements without oil, which was consistent with previous reports (Chuntrakort et al., 2011; Grainger et al., 2010; Jordan et al., 2006). Possible reasons for methane suppression by fat sources include a reduced supply of fermentable OM, depressed digestibility, and direct inhibitory effects against methane-producing microbes (Machmüller et al., 2003).

The inhibitory response of fats on methane production depends on concentration, type, fatty acid composition of fats, and nutrient composition of diets
(Beauchemin et al., 2008; Machmüller, 2006). Greater concentrations of fats do substantially decrease methane production but often exert detrimental effects on digestibility and fermentation of feeds including animal performance (Patra, 2013).

The average energy lost in the form of methane emission (expressed as consumed energy) was $3.4 \%$ in the animals receiving the supplements with oil and 3.9\% in the supplements without oil. This value is less than the value reported by the Intergovernmental Panel on Climate Change (2006) for animals consuming less than $90 \%$ concentrate in the diet ( $6.5 \%$ of GE intake). This loss of energy may have indirect but significant financial implications for production system, because it coincides with greater energy-use efficiency of the feed by the animal, and may provide an incentive for adopting mitigation strategies that can reduce methane output and improve animal performance (McGeough et al., 2010).

The inhibitory effect of fat on enteric methane emissions has been reported in the majority of studies, although the extent of inhibition varies (Brask et al., 2013; Grainger and Beauchemin, 2011). Dietary fat inhibits methanogenesis by reducing the metabolic activity and numbers of ruminal methanogens and protozoa, diminishing the quantity of feeds fermented in the rumen, and through biohydrogenation (an alternate hydrogen sink) of unsaturated fatty acids (Beauchemin et al., 2009; Johnson and Johnson, 1995; Lillis et al., 2011).

Although our study found differences in methane emissions over the fiber and GE intake, emission per kilogram of product was not affected. In this study, the mean calculated value of enteric methane emission for the treatments used here was $43.8 \mathrm{~kg} \mathrm{CH}_{4} / \mathrm{yr}$. This estimate is below the estimate of $56 \mathrm{~kg} \mathrm{CH}_{4} / \mathrm{yr}$ made by the Intergovernmental Panel on Climate Change (2006) for cattle.

Soybean hulls have an estimated feeding value comparable to that of corn when supplemented to 
animals raised on pasture, as indicated by the similar performance of these sources of energy. The use of oil supplementation may be effective to reduce enteric methane emission losses per unit of GE and EE intake for growing Nellore bulls fed Brachiaria brizantha cv. Xaraés during the rainy season.

Diet modification is one way in which the cattle industry can reduce its contribution to greenhouse gas emissions. Therefore, an ingredient that reduces methane emissions from cattle fed pasture-based diets could have an important impact on reducing the emissions in tropical regions. This study demonstrates that oil can be added to starch-based supplements to reduce methane emissions as a percentage of GE intake by $12.8 \%$ without impairing animal performance. These reductions in methane are important because total methane per animal and methane relative to GE intake are the approaches used by the Intergovernmental Panel on Climate Change (2006) in calculating methane inventories. Although studies show that diet composition affects the production of greenhouse gas by ruminants, the Intergovernmental Panel on Climate Change, in 2006, responsible for the development of methodologies for estimating global emission inventories, only made differentiation between 2 diets: diets with more than $90 \%$ concentrate $(3 \%$ of GE intake is lost as methane) and diets with less than $90 \%$ concentrate ( $6.5 \%$ of GE intake is lost as methane). This cannot be consistent with the conditions observed in the tropical regions of ruminant production systems, which use a low inclusion of concentrate in the diet of animals. Therefore, the interval of 0 to $90 \%$ concentrate for estimating the emission of methane by beef cattle is too large. Therefore, the results determined in this study, with forage:concentrate ratio (80:20) and average energy lost in the form of methane emissions of $3.65 \%$ for animals fed pasture-based diets in tropical regions, may be important for new estimates of the Intergovernmental Panel on Climate Change for global emission inventories.

\section{LITERATURE CITED}

Anderson, S. J., J. K. Merrill, M. L. McDonnell, and T. J. Klopfenstein. 1988. Digestibility and utilization of mechanically processed soybean hulls by lambs and steers. J. Anim. Sci. 66:2965-2976.

Association of Official Analytical Chemists (AOAC). 1995. Official methods of analysis. 16th ed. AOAC Int., Arlington, VA.

Barthram G. T. 1985. Experimental techniques: The HFRO sward stick. In: The hill farming research organization biennial report 1984/1985. Hill Farming Research Organization, Penicuik, UK. p. 29-30.

Beauchemin, K. A., M. Kreuzer, F. O'Mara, and T. A. McAllister. 2008. Nutritional management for enteric methane abatement: A review. Aust. J. Exp. Agric. 48:21-27. doi:10.1071/ EA07199.
Beauchemin, K. A., S. M. McGinn, C. Benchaar, and L. Holtshausen. 2009. Crushed sunflower, flax, or canola seeds in lactating dairy cow diets: Effects on methane production, rumen fermentation, and milk production. J. Dairy Sci. 92:2118-2127. doi:10.3168/jds.2008-1903.

Brask, M., P. Lund, M. R. Weisbjerg, A. L. F. Hellwing, M. Poulsen, M. K. Larsen, and T. Hvelplund. 2013. Methane production and digestion of different physical forms of rapeseed as fat supplements in dairy cows. J. Dairy Sci. 96:23562365. doi:10.3168/jds.2011-5239.

Brasil, 1997. Ministério da agricultura, Pecuária e Abastecimento, Regulamento da Inspeção Industrial e Sanitária de Produtos de Origem Animal. Food of animal origin sanitary and industry inspection. Official Gazette of the Federative Republic of Brazil, Brasília, DF.

Chuntrakort, P., M. Otsuka, K. Hayashi, and K. Sommart. 2011. Effects of oil plant use for rumen methane mitigation in in vitro gas production. Khon Kaen Agric. J. 39:246-250.

Chuntrakort, P., M. Otsuka, K. Hayashi, A. Takenaka, S. Udchachon, and K. Sommart. 2014. The effect of dietary coconut kernels, whole cottonseeds and sunflower seeds on the intake, digestibility and enteric methane emissions of Zebu beef cattle fed rice straw based diets. Livest. Sci. 161:80-89. doi:10.1016/j.livsci.2014.01.003.

Coppock, C. E., and D. L. Wilks. 1991. Supplemental fat in high energy rations for lactating cows: Effects on intake, digestion, milk yield, and composition. J. Anim. Sci. 69:38263837.

Costa, V. A. C., E. Detmann, S. D. C. Valadares Filho, M. F. Paulino, L. T. Henriques, and H. C. Mantovani. 2009. In vitro degradation of neutral detergent fiber from tropical forage quality due to supplementation with protein and/or carbohydrates. R. Bras. Zootec. 38:1803-1811.

Detmann, E., S. C. Valadares Filho, D. S. Pina, L. T. Henriques, M. F. Paulino, K. A. Magalhães, and M. L. Chizzotti. 2008. Prediction of the energy value of cattle diets based on the chemical composition of the feeds under tropical conditions. Anim. Feed Sci. Technol. 143:127-147. doi:10.1016/j.anifeedsci.2007.05.008

Dohme, F., A. Machmüller, A. Wasserfallen, and M. Kreuzer. 2000. Comparative efficiency of various fats rich in medium-chain fatty acids to suppress ruminal methanogenesis as measured with RUSITEC. Can. J. Anim. Sci. 80:473-482. doi:10.4141/A99-113.

Drouillard, J. S. 2012. Utilization of crude glycerin in beef cattle. In: H. P. S. Makkar, editor, Biofuel co-products as livestock feed - Opportunities and challenges, Food and agriculture organization of the United Nation, Rome, Italy. p. 155-161.

Duckett, S. K., J. G. Andrae, and F. N. Owens. 2002. Effect of high oil corn or added corn oil on ruminal biohydrogenation of fatty acids and conjugated linoleic acid formation in beef steers fed finishing diets. J. Anim. Sci. 80:3353-3360.

Eibs, M. S., B. J. Johnson, D. M. Wulf, B. D. Rops, and F. N. Owens. 2000. Effects of high-oil corn on feedlot performance, carcass characteristics, and meat quality. In: Proc. Plains Nutr. Counc. Spring Conf. Texas A\&M Research and Education Center, Amarillo. p. 76.

Grainger, C., and K. A. Beauchemin. 2011. Can enteric methane emissions from ruminants be lowered without lowering their production? Anim. Feed Sci. Technol. 166-167:308-320. doi:10.1016/j.anifeedsci.2011.04.021. 
Grainger, C., R. Williams, T. Clarke, A. D. G. Wright, and R. J. Eckard. 2010. Supplementation with whole cotton seed causes long-term reduction of methane emissions from lactating dairy cows offered a forage and cereal grain diet. J. Dairy Sci. 93:2612-2619. doi:10.3168/jds.2009-2888.

Hall, M. B., and M. L. Eastridge. 2014. Invited review: Carbohydrate and fat: Considerations for energy and more. Prof. Anim. Sci. 30:140-149.

Higgs, R. J., A. J. Sheahan, K. Mandok, M. E. Van Amburgh, and J. R. Roche. 2013. The effect of starch-, fiber-, or sugar-based supplements on nitrogen utilization in grazing dairy cows. J. Dairy Sci. 96:3857-3866. doi:10.3168/jds.2012-6117.

Hristov, A. N., M. Vander Pol, M. Agle, S. Zaman, C. Schneider, P. Ndegwa, and S. K. R. Karnati. 2009. Effect of lauric acid and coconut oil on ruminal fermentation, digestion, ammonia losses from manure, and milk fatty acid composition in lactating cows. J. Dairy Sci. 92:5561-5582. doi:10.3168/ jds.2009-2383.

Huws, S. A., M. R. F. Lee, S. M. Muetzel, M. B. Scott, R. J. Wallace, and N. D. Scollan. 2010. Forage type and fish oil cause shifts in rumen bacterial diversity. FEMS Microbiol. Ecol. 73:396-407.

Intergovernmental Panel on Climate Change. 2006. Emissions from livestock and manure management. In: 2006 IPCC guidelines for national greenhouse inventories. Vol. 4: Agriculture, forestry and other land use. p. 10.1-10.87. Accessed Jun.10, 2014. http://www.ipcc-nggip.iges.or.jp/ public/2006gl/pdf/4_Volume4/V4_10_Ch10_Livestock.pdf.

Johnson, A. D. 1978. Sample preparation and chemical analysis of vegetation. In: L. T. Manejte, editor, Measurement of grassland vegetation and animal production. Commonweath Agricultural Bureax, Aberustwysth, UK. p. 96-102.

Johnson, K., M. Huyler, H. Westberg, B. Lamb, and P. Zimmerman. 1994. Measurement of methane emissions from ruminant livestock using a sulfur hexafluoride tracer technique. Environ. Sci. Technol. 28:359-362. doi:10.1021/ es00051a025.

Johnson, K. A., and D. E. Johnson. 1995. Methane emissions from cattle. J. Anim. Sci. 73:2483-2492.

Jordan, E., D. K. Lovett, F. J. Monahan, J. Callan, B. Flynn, and F. P. O'Mara. 2006. Effect of refined coconut oil or copra meal on methane output and on intake and performance of beef heifers. J. Anim. Sci. 84:162-170. doi:10.2527/jas.2005-354.

Lillis, L., B. Boots, D. A. Kenny, K. Petrie, T. M. Boland, N. Clipson, and E. M. Doyle. 2011. The effect of dietary concentrate and soya oil inclusion on microbial diversity in the rumen of cattle. J. Appl. Microbiol. 111:1426-1435. doi:10.1111/j.1365-2672.2011.05154.x.

Lovett, D., S. Lovell, L. Stack, J. Callan, M. Finlay, J. Conolly, and F. P. O'Mara. 2003. Effect of forage/concentrate ration and dietary coconut oil level on methane output and performance of finishing beef heifers. Livest. Prod. Sci. 84:135146. doi:10.1016/j.livprodsci.2003.09.010.

Ludden, P. A., M. J. Cecava, and K. S. Hendrix. 1995. The value of soybean hulls as a replacement for corn in beef cattle diets formulated with or without added fat. J. Anim. Sci. 73:27062711.

Machmüller, A. 2006. Medium-chain fatty acids and their potential to reduce methanogenesis in domestic ruminants. Agric. Ecosyst. Environ. 112:107-114. doi:10.1016/j. agee.2005.08.010.
Machmüller, A., C. R. Soliva, and M. Kreuzer. 2003. Methane suppressing effect of myristic acid in sheep as affected by dietary calcium and forage proportion. Br. J. Nutr. 90:529-540. doi:10.1079/BJN2003932.

Martin, C., J. Rouel, J. P. Jouany, M. Doreau, and Y. Chilliard. 2008. Methane output and diet digestibility in response of feeding dairy cow crude linseed, extruded linseed or linseed oil. J. Anim. Sci. 86:2642-2650. doi:10.2527/jas.2007-0774.

McGeough, E. J., P. O. Kiely, K. J. Hart, A. P. Moloney, T. M. Boland, and D. A. Kenny. 2010. Methane emissions, feed intake, performance, digestibility, and rumen fermentation of finishing beef cattle offered whole-crop wheat silages differing in grain content. J. Anim. Sci. 88:2703-2716. doi: $10.2527 /$ jas.2009-2750.

McGinn, S. M., K. A. Beauchemin, T. Coates, and D. Colombatto. 2004. Methane emissions from beef cattle: Effects of monensin, sunflower oil, enzymes, yeast, and fumaric acid. J. Anim. Sci. 82:3346-3356.

Mertens, D. R. 2002. Gravimetric determination of amylase-treated neutral detergent fiber in feeds with refluxing in beaker or crucibles: Collaborative study. J. AOAC Int. 85:1217-1240.

Moss, A. R., J. P. Jouany, and J. Newbold. 2000. Methane production by ruminants: Its contribution to global warming. Ann. Zootech. 49:231-254.

Nagaraja, T. G., C. J. Newbold, C. J. Van Nevel, and D. I. Demeyer. 1997. Manipulation of rumen fermentation. In: P. N. Hobson and C. S. Stewart, editors, The rumen microbial ecosystem. Blackie Acad. Prof. Press, London, UK. p. 523-632.

NRC. 2000. Nutrient requirements of beef cattle. 7 th rev. ed. Natl. Acad. Sci., Washington, DC.

Palmquist, D. L., and T. C. Jenkins. 1980. Review: Fat in lactation rations. J. Dairy Sci. 63:1-14. doi:10.3168/jds.S00220302(80)82881-5.

Parsons, G. L., M. K. Shelor, and J. S. Drouillard. 2009. Performance and carcass traits of finishing heifers fed crude glycerin. J. Anim. Sci. 87:653-657. doi:10.2527/jas.20081053.

Patra, A. K. 2013. The effect of dietary fats on methane emissions, and its other effects on digestibility, rumen fermentation and lactation performance in cattle: A meta-analysis. Livest. Sci. 155:244-254. doi:10.1016/j.livsci.2013.05.023.

Patra, A. K., and Z. Yu. 2013. Effects of coconut and fish oils on methane production, fermentation, abundance and diversity of rumen microbial populations in vitro. J. Dairy Sci. 96:1782-1792. doi:10.3168/jds.2012-6159.

Saliba, E. O. 2005. Use of indicators: Past, present and future. In: Proceedings of Conference of Markers on Animal Nutrition, Belo Horizonte, Brazil. p. 4-22.

Santana, M. C. A., V. B. P. Euclides, A. B. Mancio, S. R. Medeiros, J. A. R. Costa, and R. L. Oliveira. 2013. Intake and performance of yearling steers grazing guineagrass (Panicum maximum cv. Tanzânia) pasture supplemented with different energy sources. Asian-Australas. J. Anim. Sci. 26:349-357.

Sullivan, H. M., J. K. Bernard, H. E. Amos, and T. C. Jenkins. 2004. Performance of lactating dairy cows fed whole cottonseed with elevated concentrations of free fatty acids in the oil. J. Dairy Sci. 87:665-671. doi:10.3168/jds.S00220302(04)73209-9.

Valadares Filho, S. C., P. A. S. Machado, M. L. Chizzotti, H. F. Amaral, C. A. Magalhães, V. R. Rocha, Jr., and E. R. Capelle. 2010. CQBAL 3.0. Brazilian tables of the chemical composition of feeds for ruminants. http://cqbal.agropecuaria.ws/ webcqbal/en/index.php (Accessed Dec. 10, 2014) 
Valente, T. N. P., E. Detmann, A. C. Queiroz, S. C. Valadares Filho, D. I. Gomes, and J. F. Figueiras. 2011. Evaluation of ruminal degradation profiles of forages using bags made from different textiles. R. Bras. Zootec. 40:2565-2573. doi:10.1590/ S1516-35982011001100039.

Van Soest, P. J., J. B. Robertson, and B. A. Lew. 1991. Methods for dietary fiber, neutral detergent fiber, and nonstarch polysaccharides in relation to animal nutrition. J. Dairy Sci. 74:3583-3597.

Westberg, H. H., K. A. Johnson, M. W. Cossalman, and J. J. Michael. 1998. A SF6 tracer technique: Methane measurement from ruminants. In: USEPA - Evaluating ruminant livestock efficiency projects and programs. Washington State University, Pullman, Washington. p. 40.
Yang, S. L., D. P. Bu, J. Q. Wang, Z. Y. Hu, D. Li, H. Y. Wei, L. Y. Zhou, and J. L. Loor. 2009. Soybean oil and linseed oil supplementation affect profiles of ruminal microorganisms in dairy cows. Animal 3:1562-1569. doi:10.1017/ S1751731109990462.

Zinn, R. A., S. K. Gulati, A. Plascencia, and J. Salinas. 2000. Influence of ruminal biohydrogenation on the feeding value of fat in finishing diets for feedlot cattle. J. Anim. Sci. 78:1738-1746. 